\title{
Capabilities and Performances of the Selective Laser Melting Process
}

\author{
Sabina L. Campanelli, Nicola Contuzzi, \\ Andrea Angelastro and Antonio D. Ludovico \\ Polytechnic of Bari, Department of Management and Mechanical Engineering, \\ Viale Japigia, 182 \\ Italy
}

\section{Introduction}

The current market is in a phase of accelerated process of change, that leads companies to innovate in new techniques or technologies to respond as quickly as possible to the everchanging aspects of the global environment. The economy of a country is heavily dependent on new and innovative products with very short development time.

Companies, currently, have considerable success, only if they develop the ability to respond quickly to changing of customer needs and to use new innovative technologies. In this context, the companies that can offer a greater variety of new products with higher performance resulting in advantage over the other.

At the heart of this environment there is a new generation of customers, who forced organizations to research new technologies and techniques to improve business processes and accelerate product development cycle. As a direct result, factories are forced to apply a new philosophy of engineering as the Rapid Response to Manufacturing (RRM). The concept of the RRM uses products previously designed to support the development of new products.

The RRM environment was developed by integrating the various technologies, such as CAD-based modelling, the knowledge-based engineering for integrated product and process management and the direct production concepts. Direct production uses prototyping, tooling and rapid manufacturing technologies to quickly test the design and build the part (Cherng et al., 1998).

Among RRM technologies, Rapid (RP) and Virtual (VP) Prototyping are revolutionizing the way in which artefacts are designed.

Rapid Prototyping (RP) technologies embraces a wide range of processes for producing parts directly from CAD models, with little need for human intervention; so, designers can produce real prototypes, even very complex, in a simple and efficient way, allowing them to check the assembly and functionality of the design, minimizing errors, product development costs and lead times (Waterman \& Dickens, 1994).

The SLS technology was developed, like other RP technologies, to provide a prototyping technique to decrease the time and cost of the product cycle design. It consists of building a three dimensional object layer by layer selectively sintering or partial melting a powder bed by laser radiation. 
The SLS objects appear as rigid and porous, in fact, the density of the material depends on the temperature evolution. The molten layer, when the temperature decreases, solidifies and binds to the underlying layer, but the presence of the liquid phase, although happens for a few time, leads to a shrinkage of the powder-liquid mixture. Thus, the porosity cannot be completely eliminated, but the density of the manufactured part is usually higher than the powder density. Moreover, due to temperature variation, mechanical stresses are induced. As a consequence, the final state of the part (dimensions, density, residual stress levels, etc.) strongly depends on the process evolution (Kolossov et al., 2004).

The success of SLS as a rapid prototyping and rapid manufacturing technology results mainly to the possibility to process almost any type of materials (polymers, glass-filled nylon, metal and composites) to accommodate multiple applications throughout the manufacturing process, but high density is desired for the production of functional metallic parts.

The Selective laser sintering process can be indirect or direct:

1. The indirect SLS uses a polymer coating of about $5 \mu \mathrm{m}$ in thickness for metal powders and ceramics. The metal powder particles are coated with the polymer and the action of the laser melts the polymer, bonding the metal particles together to produce a green part. It is necessary, therefore, a post-treatment in the oven at high temperature, so remove the polymer and sintering particles by creating a metal-metal link.

2. In Direct SLS (DMLS) a low melting point component is melted and employed as a matrix in which the higher melting point components sit. In this process are used or a single powder with two different grain sizes (a slight and a coarse grains) or binary systems. Typical binary phase systems investigated include $\mathrm{Ni}-\mathrm{Cu}, \mathrm{Fe}-\mathrm{Cu}$ and $\mathrm{Cu}-$ $\mathrm{Pb} / \mathrm{Sn}$ (Kruth et al. 2008; Lu et al., 2001). The disadvantage of the above processing routes is that the components produced exhibit the mechanical properties and characteristics of their weakest composite phase, thus lacking the full mechanical functionality required for heavy-duty tasks (Dewidar et al., 2008).

To obtain high density, for functional metallic prototypes, parts or tools, different powder binding mechanisms is necessary, so, Selective Laser Melting (SLM) was developed.

The SLM represents a variation from the classical SLS. The substantial differences compared to the latter are:

- using an integral powder metal without adding low melting point elements;

- the need to provide a much higher energy density, to bring fusion the powder.

In SLM near full density parts can be produced without the need for post-processing steps, while the same materials can be used as in serial production.

The advantage is to get an element a massively dense, close to $100 \%$, with metallurgical characteristics similar to the objects achievable with conventional production processes and without need of post-treatments.

The laser must have a greater power than the SLS and at the end of the process the manufactured objects is quite similar to series production, in fact, it does not require special surface finishes and may be subjected quietly at conventional machining.

In addition, with Selective Laser Melting process there is the theoretical possibility of produce any complex geometry. This result is attributable to Layer Manufacturing, each individual point of the component can be reached by the laser beam at any time during the process. In contrast, the process isn't competitive for large lots or for slight complex parts, because the technique is rather slow and, therefore, very expensive. 
In order to reach a high density, the metallic powder particles are fully molten, laser melting process is accompanied by the development of residual stresses, that derive from high thermal gradients in the material. These stresses can cause distortion of the part, cracks or delaminations (Fischer et al., 2003; Pohl et al., 2001; Nickel et al., 2001).

Another undesirable phenomenon is the vaporization, that occurs when the bed of powder is irradiated with high energy intensity. During the laser melting process, the temperature of the powder particles exposed to the laser beam exceed the melting temperature of the material. A further increase in temperature (about twice the material melting temperature) causes the evaporation of the powder, so, there are a fast-moving expansion of evaporated particles, which generate a overpressure on the melted zone and the material is ejected from its bed (Hauser et al., 2003).

Another problem that may occur during the SLM process is the "balling" or spheroidization phenomenon, i.e. the formation of isolated spheres with a diameter equal to the laser beam focus, which inhibits deposition and decreases the density of produced part. It occurs when the molten material is unable to fully wet the substrate because of surface tension.

The phenomenon is caused by an excessive amount of energy, which gives to the melted powder a too low value in viscosity (Nickel et al., 2001; Kannatey-Asibu, 2009; Niu \& Chang, 1999).

The aim of this chapter will be to describe capabilities and performances of the SLM process. First, the capacity of the system in realizing micro-components with both high dimensional accuracy and maximum density, with mechanical properties similar to those assured by traditional technologies, will be investigated. Later on it, the chapter will describe some applications of the SLM process, such as the manufacture of moulds with conformal channels, of customised jigs for welding and the design and fabrication of reticular structures, to be used in automotive and aerospace field or in the medical one for custom prosthesis fabrication.

\section{The process}

Selective Laser Melting Equipment technology provide a laser system, a set of optical laser beam focusing, a powder feeding system (loader and roller or coater) and a control center (Fig. 1).

The piece to be achieved should be drawn using a three dimensional solid or surface modeler, then the mathematical model is developed in a CAD format compatible with the management software of the RP machine.

The currently accepted graphic standard by all manufacturers is the STL (solid to layer), introduced by 3D Systems, which provides the mesh of internal and external surfaces of the workpiece through triangular elements.

The STL file is then processed for the orientation and slicing phases. The first step allows to select the best growth direction of the piece, which greatly influences the dimensional accuracy and production time.

The slicing step, instead, is a critical because it determines the accuracy of the product; in fact, it provides a breakdown of the object with orthogonal planes to the direction of growth, obtaining the contour of each section, which describes the path of scanning beam laser, and the thickness of the layers.

The process takes place inside an enclosed chamber, filled with nitrogen gas, to minimize oxidation and degradation of the powdered material. 


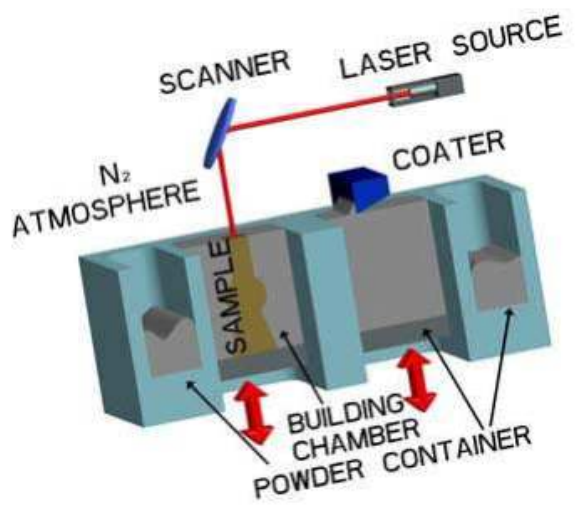

Fig. 1. SLM equipment

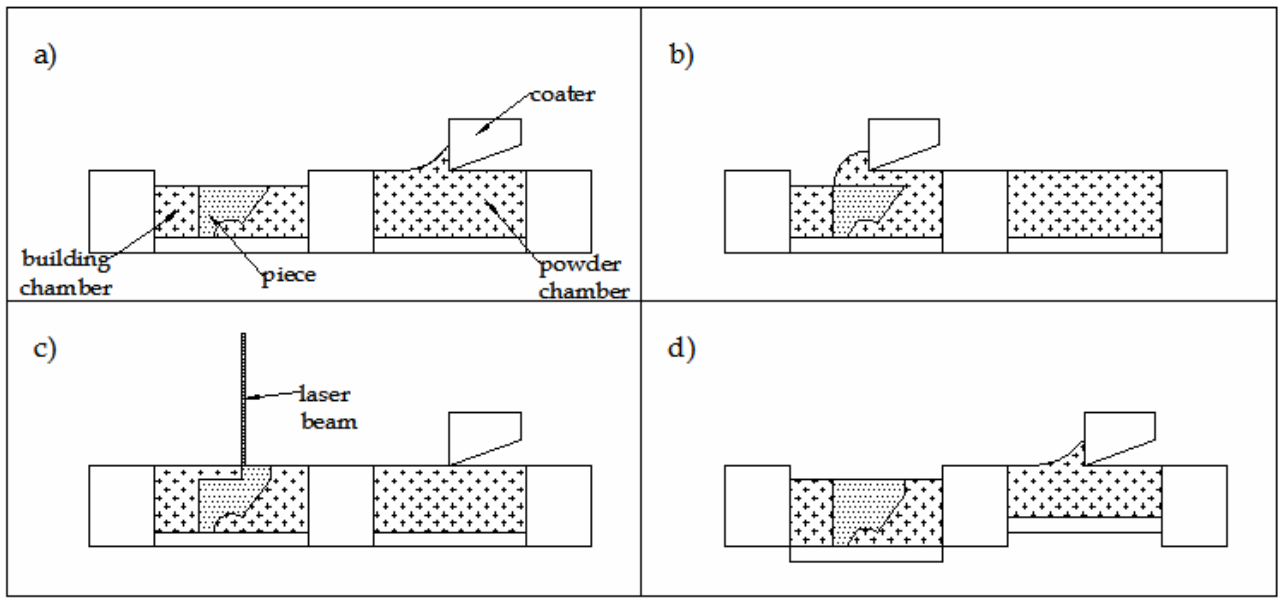

Fig. 2. Phases of the SLM process

In some technological solutions, to minimize distortions and residual stresses, the powder in the build platform is maintained at an elevated temperature (below the melting point of the powdered material); in other technological solution the preheating phase is used to minimize porosity on the built piece (Slocombe et al., 2001)

The most common solutions include:

- infrared heaters, that are placed about the building platform to maintain an elevated temperature around the part that being formed;

- feed cartridges, to pre-heat the powder prior to spreading over the build area.

- resistive heaters, around the building platform.

This powder pre-heating and the next maintenance of an elevated and uniform temperature, within the build platform, is necessary, also, to minimize the power laser requirements of the process, to improve absorption of the laser beam, to prevent warping of the part during the build due to non-uniform thermal expansion and contraction (curling), to reduce the temperature gradients and improve the wetting properties. 
Preheating of the powder is used to improve absorption of the laser to reduce the temperature gradients and improve the wetting properties.

The Control Centre commands the RP machine power system: the powder room is raised by an amount such that the deposited powder by roller or coater, on the surface of the building chamber, deposits a layer of a thickness equal to that given during slicing, while the working chamber decreases the thickness of a layer (Fig.2a).

The coater deposits, in uniform way, the powder on the building chamber (Fig.2b).

The laser beam selectively scans the surface of the powder, that is, then, sintered (Fig.2c).

When the first two-dimensional layer is created, the process is repeated until the object is built, with a lowering, equal to the thickness of the layer, of the building chamber (Fig. 2.d) and the subsequent distribution of the powder with the coater and the selective scanning by the laser beam. Surrounding powder remains loose and serves as support for subsequent layers, thus eliminating the need for the secondary supports which are necessary for photopolymer vat processes.

For pre-heated solution, a cooling period is required. If the high temperature parts and powders are prematurely exposed to external atmosphere, they may degrade for the presence of oxygen and the powder cannot be recovered and used for further processing; also, the built objects may warp due to uneven thermal contraction. So, to allow the parts to uniformly come to a low-enough temperature that they can be handled and exposed to ambient temperature and atmosphere.

Finally, the parts are removed from the powder bed, loose powder is cleaned off the parts, and further finishing operations, if necessary, are performed.

\section{Materials}

In order to develop a process that can produce functional high strength parts, in a first time, successful results, with DMLS, have been obtained with high-strength powder mixtures, that containing only two metal powders, such as $\mathrm{Fe}-\mathrm{Cu}, \mathrm{WC}-\mathrm{Co}, \mathrm{TiC}-\mathrm{Ni} / \mathrm{Co} / \mathrm{Mo}$, TiCN-Ni, $\mathrm{TiB}_{2}-\mathrm{Ni}, \mathrm{ZrB}_{2}-\mathrm{Cu}$ and $\mathrm{Fe}_{3} \mathrm{C}-\mathrm{Fe}$, melting only the powder having the lower melting point (Kruth et al., 1997; Kruth et al., 1996; Laoui et al., 1998).

However, a substantial amount of work has been carried out in the field of laser sintering of metal parts, some of which are as follows. Niu and Chang (Niu and Chang, 1998; Niu and Chang, 1999; Niu and Chang, 1999; Niu and Chang, 2000) have studied the SLS process on HSS powder with a carbon di-oxide laser of 25 W, while Fischer (Fischer et al., 2003) has studied the behaviour of commercial titanium. Song (Song, 1997) have performed experiments on direct sintering of pre-alloyed bronze as a low melting metallic powder on a laboratory test facility. Abe (Abe et al., 2001) has studied the behavior of nickel base alloys and has reported that the process does not exhibit balling phenomenon but only part deflections and cracking.

At this day, few studies have been performed on SLM process. Badrossamay (Badrossamay \& Childs, 2007) has performed a further studies on M2 tool steel, 316L and 314S-HC stainless steel, while Abe (Abe et al., 2001) has investigated the effects of a single scanning test on several kinds of materials: aluminium, copper, iron, stainless steels (SUS 316L), chromium, titanium and nickel-based alloy. Kruth (Kruth et al., 2004) has studied a mixture of different types of particles $\left(\mathrm{Fe}, \mathrm{Ni}, \mathrm{Cu}\right.$ and $\mathrm{Fe}_{3} \mathrm{P}$ ) specially developed for SLM. 


\section{Experimental tests and analysis of results}

\subsection{Experimental plan}

Experimental tests have been performed in this work to understand the capabilities of the SLM process in terms of density, roughness, dimensional accuracy and mechanical properties.

Several process parameters can be modified in order to obtain optimum quality of laser sintered samples. Some of these parameters are related to the process (single layer thickness, scan velocity, hatch spacing, scan strategy), others depend on the laser (laser power, spot diameter, wavelengths, the energy of the pulse laser), the type of material and other characteristics of the used powder (such as particle size, distribution, shape, material type, the percentage composition of materials), others by the final component which is to be realized (shape, size, etc...).

The energy density $E_{d}$ of a single track can be calculated by the relation between laser power $(\mathrm{P})$, scan speed (v) and spot diameter (d) (Eq. 1) (Lu, 2009):

$$
E_{d}=\frac{P}{v \cdot d}\left[\frac{J}{m m^{2}}\right]
$$

where:

- $\quad P$ is the laser power used to scan a part;

- $v$ is the scan speed or the velocity by which the laser beam moves over the powder surface.

- $\quad d$ is the spot diameter, equal to $0.2[\mathrm{~mm}]$.

A full factorial plan ( $3^{2}$ plan) was used to project experiments. A contemporary variation of the two parameters, scanning speed (measured in $\mathrm{mm} / \mathrm{s}$ ) of the laser power (measured in Watt) was considered, in order to find out the parameters combination leading to the maximum mechanical properties. The combination of these two parameters is responsible for the melting mechanism and influence the quality of built parts.

Nine samples were built, with three levels of scanning speed $(180,200,220)$ and three levels of laser power $(57,86,100)$. Moreover, five replications for each combination of the parameters were realized.

\subsection{Machine set up}

The machine used to perform experiments was equipped with a Rofin Nd:YAG laser source characterized by a wavelength of $1.064 \mu \mathrm{m}$, a spot diameter of $200 \mu \mathrm{m}$ and a maximum output power of $100 \mathrm{~W}$. The laser beam was moved over the powder surface by means of scanning mirrors in order to draw selectively every layer of the powder.

The powder deposition system consisted in a building chamber, a powder chamber and a coater. Powder layers were deposited in one direction using a coater and the layer thickness was set to $30 \mu \mathrm{m}$. Moreover, the chamber was filled, in slight overpressure, with nitrogen to prevent oxidation of the parts and to reduce the initial oxygen level at $0.8 \%$.

\subsection{Material}

A material with the typical composition of maraging steels, reinforced with cobalt, was used for the present study. Specifically, the composition was very close to the 18 Ni Marage 300 steel and the powder had spherical particles with average size below $40 \mu \mathrm{m}$. The chemical composition of the used powder, determined by Energy Dispersive X-ray (EDX) analysis, 
consisted in 4.2 wt.\% Mo, 0.88 wt.\% Ti, 65.9 wt.\% Fe, 10.2 wt.\% Co, 18.8 wt.\% Ni and 0.02 wt. \% C.

Maraging steels are a special class of low-carbon ultra-high-strength steels, which derive their strength not from carbon, but from precipitation of inter-metallic compounds; they were developed for high performance applications, especially those in which high strength and good toughness are required.

$18 \mathrm{Ni}$ Marage 300 steel presents excellent mechanical properties, high value of yield and tensile strength, toughness, ductility and impact strength, high fatigue limit, high compressive strength, hardness and wear resistance suitable for many machining tools.

This type of steel is conventionally used for produce tools suitable for complex machining, to achieve high-performance industrial parts (aerospace applications), for manufacturing of dies for hot injection moulding, for inserts for moulds of all standard thermoplastic materials, for casting and for the direct realization of objects for engineering applications.

\subsection{Mechanical characterisation of built samples}

Small square samples of $15 \times 15 \times 10 \mathrm{~mm}$ were built to measure density, hardness and to study microstructure.

First, density was measured with the 'Archimedes-method' by weighting the samples in air and subsequently in ethanol after coating them with a lacquer. The coating prevented absorption of ethanol by the specimen during measurements.

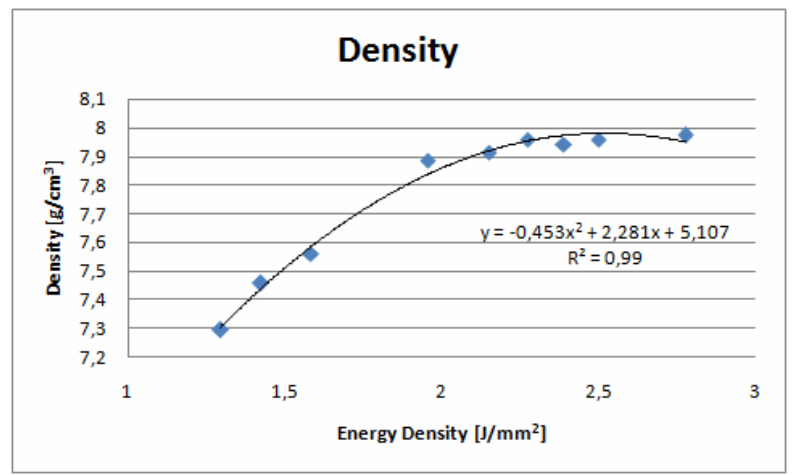

Fig. 3. Density versus Energy Density

Fig. 3 shows the tendency of Density versus the Energy Density $E_{d}$. Values of Ed were calculated by means of Eq. 1.

It is evident that density increases with the increase of $E_{d}$ and it is maximal for the maximum $E_{d}$, which means scan speed and laser power set respectively to the minimum $(180 \mathrm{~mm} / \mathrm{s})$ and the maximum value $(100 \mathrm{~W})$ of the considered range. A maximum value of $8.0 \mathrm{~g} / \mathrm{m}^{3}$ was found for density; thus the porosity was approximately $0.01 \%$. This means that it was possible to produce nearly full dense parts with properties comparable to those of the bulk material.

Hardness and tensile tests were performed on specimens built with the maximum density, setting the scan speed to $180 \mathrm{~mm} / \mathrm{s}$ and laser power to $100 \mathrm{~W}$.

Rockwell $\mathrm{C}$ test was used for determining hardness. Experimental results gave an average value of $34 \mathrm{HRC}$. 
Tensile tests were performed using an Instron 4467 machine equipped by an extensometer (with a $12.5 \mathrm{~mm}$ gage length and maximum elongation of $5 \mathrm{~mm}$ ). Results of tensile test brought to a value of $985 \mathrm{MPa}$ for Yield Strenght, $1145 \mathrm{MPa}$ for Tensile Strength and $7.6 \%$ for Elongation to break.

Fig.4(a) and Fig.4(b), respectively, show micrographs at magnifications 200X and 1000X obtained with an optical microscope. It is evident that the metal powder is completely fused and constituted by molten/re-solidified zones with curved edges (approximately parabolic). The laser tracks overlap in order to produce a non-porous part. This means that each part is welded onto the layers surrounding it. The presence of pores is very limited as it is possible to see from black spots in the pictures.
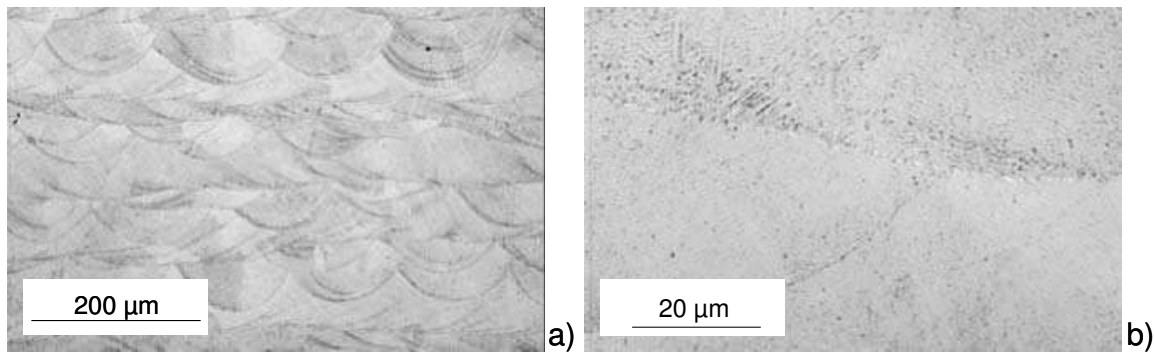

Fig. 4. 200x magnification (a) and 1000x magnification (b) of the sample obtained with $\mathrm{P}=100 \mathrm{~W}$ and $\mathrm{v}=180 \mathrm{~mm} / \mathrm{s}$

\subsection{Dimensional accuracy}

A specific part test was developed in order to test the dimensional accuracy of SLM parts with the maximum density achieved. The proposed geometry with maximum dimensions $70 \times 70 \times 25 \mathrm{~mm}$ is shown in (Fig. 5). It was thought to determine capabilities of the process in terms of:

- minimum feasible feature size;

- dimensional achievable accuracy.

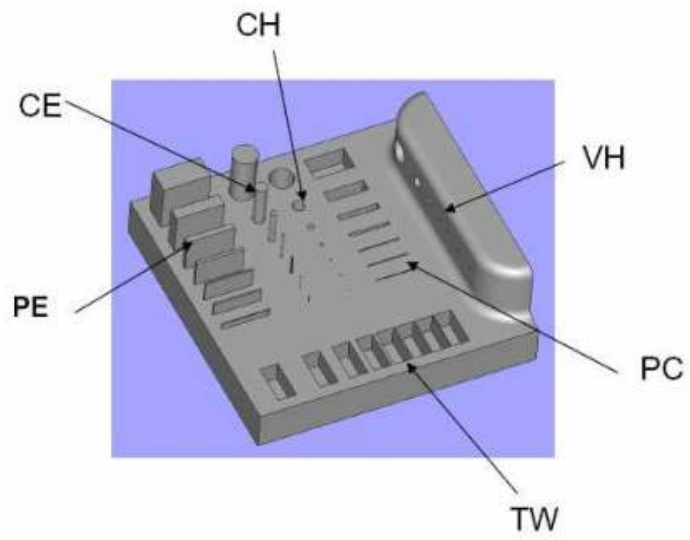

Fig. 5. Benchmark geometry 
The feasible precision and resolution of the process were tested by:

- $\quad$ cylindrical holes $(\mathrm{CH})$, ranging from 0.2 to $6 \mathrm{~mm}$ diameter $(\mathrm{CH} 1 . \mathrm{CH} 2, \mathrm{CH} 3, \mathrm{CH} 4, \mathrm{CH}$, $\mathrm{CH} 6, \mathrm{CH} 7$ );

- cylindrical extrusions (CE), ranging from 0.2 to $6 \mathrm{~mm}$ diameter (CE1, CE2, CE3, CE4, CE5, CE6, CE7);

- $\quad$ parallelepiped extrusions (PE), ranging from 0.2 to $6 \mathrm{~mm}$ thickness (PE1, PE2, PE3, PE4, PE5, PE6, PE7);

- $\quad$ parallelepiped cavities (PC), ranging from 0.2 to $6 \mathrm{~mm}$ width (PC1, PC2, PC3, PC4, PC5, PC6, PC7);

- $\quad$ vertical holes (VH) ranging from 0.2 to $6 \mathrm{~mm}$ diameter (VH1, VH2, VH3, VH4, VH5, VH6, VH7);

- $\quad$ thin walls (TW) ranging from 0.2 to 6 mm thickness (TW1, TW2, TW3, TW4, TW5, TW6, TW7);

The built benchmark (Fig. 6) was measured using a coordinate measuring machine (DEMeet 400) together with an optical microscope.

Fig. 6 shows a picture of the built benchmark. It is evident how all designed features could be realized, except for cylindrical extrusions CE1, CE2, CE3. They were probably built, but they were removed by the coater during the deposition of the powder.

The dimensional error $\mathrm{E} \%$ was introduced in order to perform an analytical study of the accuracy (Eq. 2). In this equation $N_{d}$ and $M_{d}$ represent respectively the nominal and the measured dimension.

$$
E \%=\frac{N_{d}-M_{d}}{N_{d}} \cdot 100
$$

Results of measurements (Table 3) showed that it was possible to build:

- thin walls with a maximum error of $15 \%$ for a thickness of $0.2 \mathrm{~mm}$ and with a minimum error of $1.17 \%$ for a thickness of $6 \mathrm{~mm}$;

- parallelepiped cavities with a maximum error of $20 \%$ for a width of $0.2 \mathrm{~mm}$ and with a minimum error of $4 \%$ for a width of $6 \mathrm{~mm}$;

- parallelepiped extrusions with a maximum error of $20 \%$ for a thickness of $0.2 \mathrm{~mm}$ and with a minimum error of $1.33 \%$ for a thickness of $6 \mathrm{~mm}$;

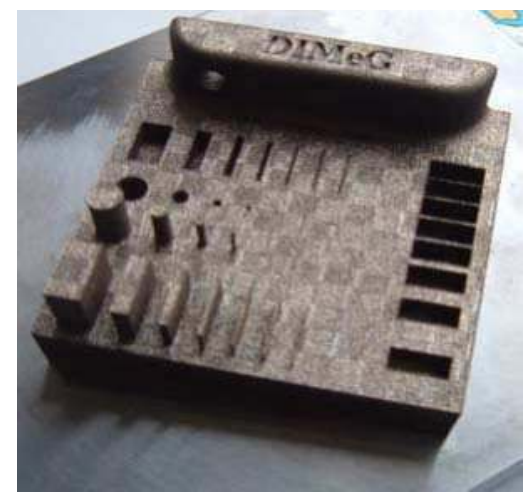

Fig. 6. Built benchmark 
New Trends in Technologies: Devices, Computer, Communication and Industrial Systems

\begin{tabular}{|c|c|c|c|c|}
\hline Element & \begin{tabular}{|c|}
$\begin{array}{c}\text { Measurable } \\
\text { size }\end{array}$ \\
\end{tabular} & $\begin{array}{c}\text { Nominal dimension } \\
{[\mathrm{mm}]}\end{array}$ & $\begin{array}{l}\text { Measured Dimension } \\
{[\mathrm{mm}]}\end{array}$ & $\mathrm{E} \%$ \\
\hline CE1 & diameter & 0.2 & - & - \\
\hline CE2 & diameter & 0.3 & - & - \\
\hline CE3 & diameter & 0.4 & - & - \\
\hline$\overline{C E} 4$ & diameter & 0.8 & 0.87 & -8.75 \\
\hline CE5 & diameter & 1.5 & 1.6 & -6.67 \\
\hline CE6 & diameter & 3 & 2.99 & 0.33 \\
\hline CE7 & diameter & 6 & 5.99 & 0.17 \\
\hline $\mathrm{CH} 1$ & diameter & 0.2 & 0.23 & -15.00 \\
\hline $\mathrm{CH} 2$ & diameter & 0.3 & 0.34 & -13.33 \\
\hline $\mathrm{CH} 3$ & diameter & 0.4 & 0.41 & -2.50 \\
\hline $\mathrm{CH} 4$ & diameter & 0.8 & 0.82 & -2.50 \\
\hline $\mathrm{CH} 5$ & diameter & 1.5 & 1.53 & -2.00 \\
\hline $\mathrm{CH} 6$ & diameter & 3 & 2.91 & 1.67 \\
\hline $\mathrm{CH} 7$ & diameter & 6 & 5.94 & 1.00 \\
\hline PE1 & thickness & 0.2 & 0.16 & 20.00 \\
\hline PE2 & thickness & 0.3 & 0.32 & -6.67 \\
\hline PE3 & thickness & 0.4 & 0.36 & 10.00 \\
\hline PE4 & thickness & 0.8 & 0.88 & -10.00 \\
\hline PE5 & thickness & 1.5 & 1.64 & -9.33 \\
\hline PE6 & thickness & 3 & 3.24 & -8.00 \\
\hline PE7 & thickness & 6 & 6.08 & -1.33 \\
\hline PC1 & width & 0.2 & 0.24 & -20.00 \\
\hline PC2 & width & 0.3 & 0.33 & -10.00 \\
\hline PC3 & width & 0.4 & 0.44 & -10.00 \\
\hline PC4 & width & 0.8 & 0.84 & -5.00 \\
\hline PC5 & width & 1.5 & 1.37 & 8.67 \\
\hline PC6 & width & 3 & 2.84 & 5.33 \\
\hline PC7 & width & 6 & 5.43 & 9.50 \\
\hline VH1 & diameter & 0.2 & 0.25 & -25.00 \\
\hline VH2 & diameter & 0.3 & 0.36 & -20.00 \\
\hline VH3 & diameter & 0.4 & 0.43 & -7.50 \\
\hline VH4 & diameter & 0.8 & 0.85 & -6.25 \\
\hline VH5 & diameter & 1.5 & 1.55 & -3.33 \\
\hline VH6 & diameter & 3 & 2.73 & 9.00 \\
\hline VH7 & diameter & 6 & 5.46 & 9.00 \\
\hline TW1 & thickness & 0.2 & 0.17 & 15.00 \\
\hline TW2 & thickness & 0.3 & 0.33 & -10.00 \\
\hline TW3 & thickness & 0.4 & 0.37 & 7.50 \\
\hline TW4 & thickness & 0.8 & 0.75 & 6.25 \\
\hline TW5 & thickness & 1.5 & 1.44 & 4.00 \\
\hline TW6 & thickness & 3 & 3.06 & -2.00 \\
\hline TW7 & thickness & 6 & 6.07 & -1.17 \\
\hline
\end{tabular}

Table 3. Results of measurements 
- cylindrical extrusions with a maximum error of $8.75 \%$ for a diameter of $0.8 \mathrm{~mm}$ and with a minimum error of $0.17 \%$ for a diameter of $6 \mathrm{~mm}$;

- cylindrical holes with a maximum error of $15 \%$ for a diameter of $0.2 \mathrm{~mm}$ and with a minimum error of $1 \%$ for a diameter of $6 \mathrm{~mm}$;

- vertical holes with a maximum error of $25 \%$ for a thickness of $0.2 \mathrm{~mm}$ and with a minimum error of $3.33 \%$ for a thickness of $1.5 \mathrm{~mm}$.

The following considerations can be drawn:

The process has a good accuracy for nominal dimensions over $0.4 \mathrm{~mm}$; $\%$ increases for values lower than $0.4 \mathrm{~mm}$ because the nominal dimension is gradually approaching to the laser spot diameter.

\section{SLM Applications}

\subsection{Cellular structures}

The cellular metal structures have been used in various industrial applications such as heat exchangers, in reconstructive surgery, in chemistry, in automotive and aerospace industries. They possess valuable characteristics as low density, high strength, good energy absorption, good thermal and acoustic properties (Dotcheva et al., 2008).

Periodic cellular structures are highly porous structures, with only $20 \%$ or less of their internal volume occupied by solid material (Evans et al., 2001). These advantageous characteristics make them very desirable, but difficulties in their production limits their application. Layer manufacturing technologies such as Direct Metal Additive Manufacturing, the Electron Beam Melting, the Direct Metal Laser Sintering and Selective Laser Melting (SLM), allow the manufacture of solid parts of any geometry, using laser technology and layers of metal powder.

The SLM technology offers the possibility to produce parts with complex engineering materials (stainless steel, tool steel, titanium alloy and cobalt-chromium alloys) relatively quickly, directly from a 3D CAD data.

This gives designers the freedom to use the cellular materials where there is the need to create a better functionality of a product without sacrificing its mechanical properties.

The SLM technology, used as a process for the production of cellular structures, can be beneficial as it has:

- The complete freedom in defining the geometry of the part (Kruf et al., 2006);

- $\quad$ The reduction of the production cycle (Santos et al., 2006).

In this field, few works have been performed.

Rehme (Rehme,2010) have been investigated the manufacturability and scaling laws for mechanical properties of periodic lattice structures built with SLM technology. In his work has built eight different unit cell types, that possess low relative density and response well to compressive load. Dotcheva et al. (Dotcheva et al., 2008) have been used cellular truss structures as a core material for injection moulding tools. They investigated the capabilities of SLM technology for fast building of 3D complex geometry and to improve the thermal management of the injection moulding process.

At DIMeG of the Polytechnic of Bari, has been tested the ability of the SLM to build lattice structures (Contuzzi, 2010).

To test the process, it was chosen, for its versatility, a lattice structure reinforced vertically and with $45^{\circ}$ truss columns (Fig. 7 ). 


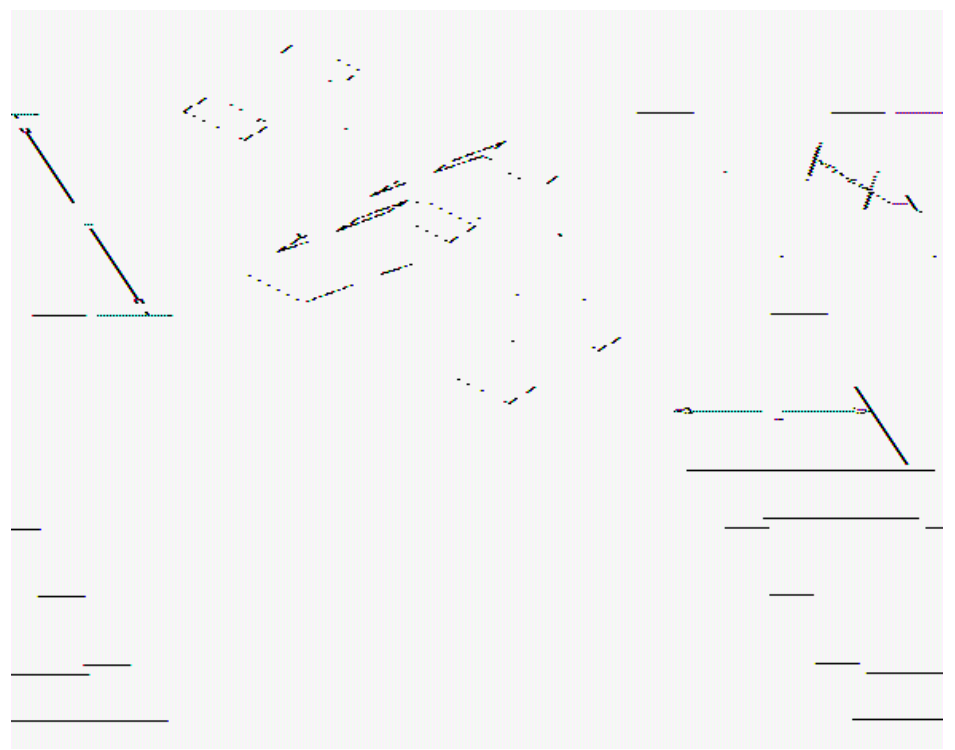

Fig. 7. Single cell and its dimension

The studied configurations are:

A. cell of $2 \mathrm{~mm}$ (L) with side of the truss of $500 \mu \mathrm{m}$ (l) (Fig. 8);

B. cell of $3 \mathrm{~mm}$ (L) with side of the truss of $700 \mu \mathrm{m}$ (l) (Fig. 9).

Overall, the configuration A ( 2 mm cells, $500 \mu \mathrm{m}$ side truss) has the dimensions of $16 \times 16 \times 16$ $\mathrm{mm}$, while the $\mathrm{B}$ configuration ( $3 \mathrm{~mm}$ cells, $700 \mu \mathrm{m}$ side truss) has the dimensions of 21x21×15 mm.

Between multi-functional applications of periodic cellular structures one of the most interesting is one that uses they as heat sinks (resistors).

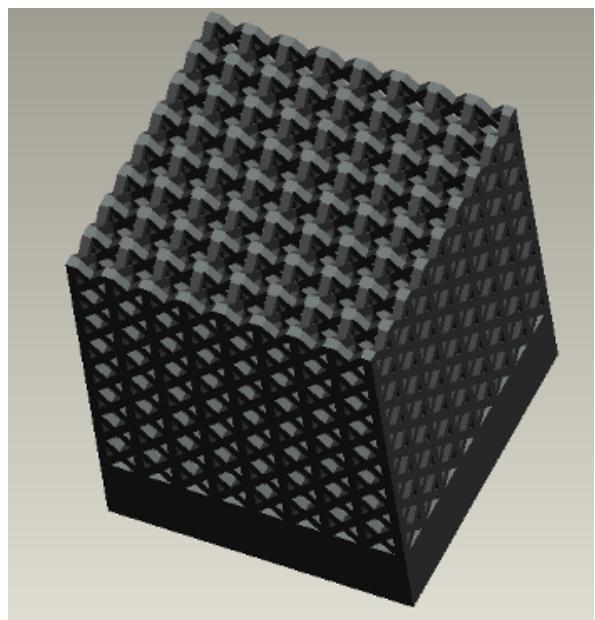

Fig. 8. CAD model of sample A 


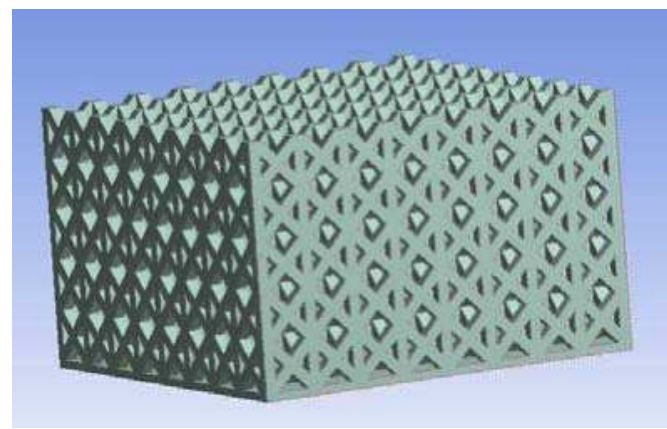

Fig. 9. CAD model of sample B

Its function is to extend the physical dimensions of the device, allowing, thus, a better heat dissipation, because it deprives heat, for Joule effect, and transfers it to the surroundings ambient, preventing the excess of the temperature limit. The presence of the heat sink leads to a reduction in overall thermal resistance, allowing, thus, the reduction of the temperature reached of the device, or, wanting exploit the maximum operating temperature, have a higher power dissipated.

The studied lattice structure have a good behavior as resistors, allowing a disposal, in both configurations, well over 100 watts (Fig. 10) at room temperature of $0^{\circ} \mathrm{C}$ and over $60 \mathrm{~W}$ at room temperature of $220^{\circ} \mathrm{C}$.

The structures show, also, good mechanical properties. A compressive test was performed (Fig. 11)

The sintered AISI MARAGE 300 has an elastic behavior almost to the breaking point, this means that, according to Timoshenko \& Gere (Gere \& Timoshenko ,1984), the lattice structure, at a certain point, begins to deform plastically, but continues to support the stress because of the hardening of the trusses, the beams themselves then collapsing for plastic instability.

For this reason the tests were not performed until the complete collapse of structures, but were stopped when the load is stable for a specified time interval. In this interval the trusses begin to destabilized, but the load is supported by the intact trusses.

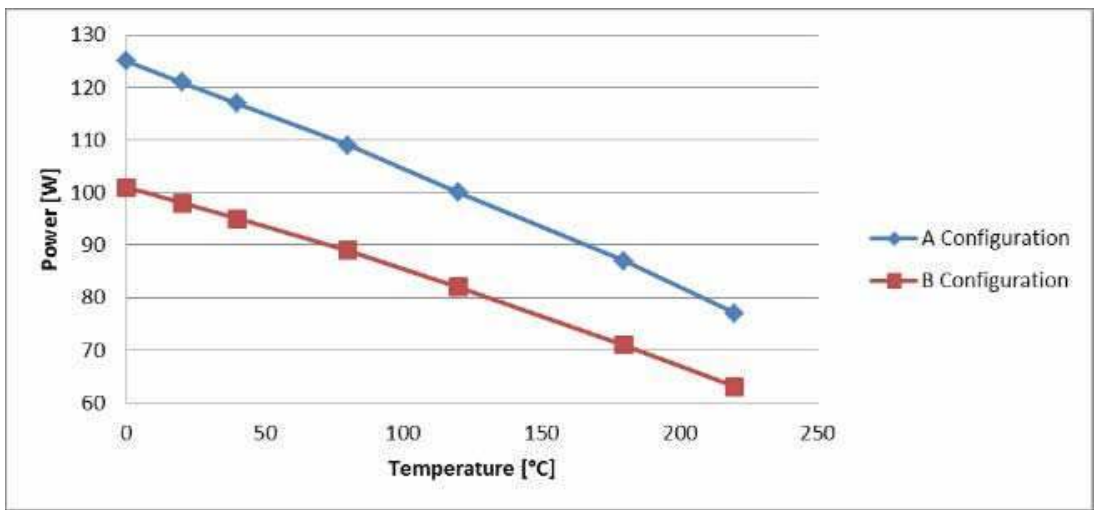

Fig. 10. Maximum power dissipated 

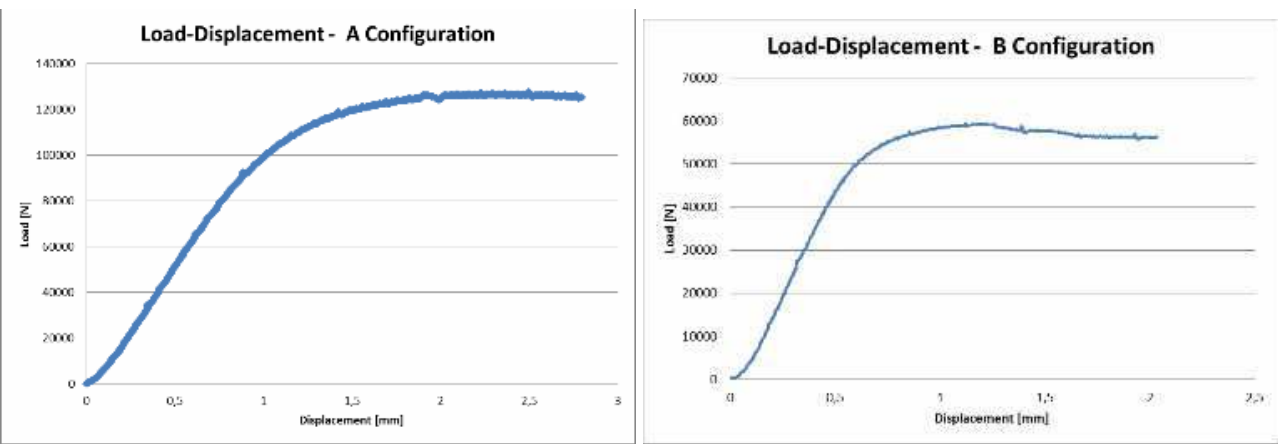

Fig. 11. Load-Displacement curve

\subsection{Tools with three-dimensional conformal channels}

In recent years, SLM have found widespread use in the field of rapid tooling, especially in the injection mould. The basic principle of injection moulding is that a solid polymer is molten and injected into a cavity inside a mould, which is then cooled and the part ejected from the machine. Therefore, the main phases in an injection moulding process involve filling, cooling and ejection. The cost-efficiency of the process is dependent on the time spent in the moulding cycle. Correspondingly, since the cooling phase is the most lenghty step among the three, it determines the rate at which the parts are produced. A reduction in the time spent on cooling the part before it is ejected would drastically increase the production rate, hence reduce costs (Dimla et al., 2005). Historically, this result has been achieved by creating several channels inside the mould and forcing a cooler liquid to circulate and conduct the excess heat away. The channels are constituted by holes as close as possible to the actual moulding area of the die. Up to now, the methods used for producing these holes rely on the conventional machining process such as drilling or boring. However, this simple technology can only create straight holes which, besides having to intersect each other and requiring the closure of entry points of the tool with a plug, cannot remain at a constant distance from the moulding area to cool it uniformly. Uneven cooling will result in an increase of the mould defects, like warpages or residual stresses, and of the cooling time. A more acceptable cooling method, the conformal cooling, is performed by the coolant flows in a pattern that closely matches the geometry of the part being moulded (Au \& Yu, 2007). The term conformal means that the geometry of the cooling channel follows the mould surface geometry. The aim is to maintain a steady and uniform cooling performance for the moulding part.

Ring et al. investigated the effectiveness of conformal channels by through the construction of three different moulds with and without conformal cooling. They showed that the conformal cooling channels technique led to significant improvements and a general reduction of the cycle time while increasing heat transfer (Ring et al., 2002).

A comparison between conformal channels and drilled cooling channels has also been conducted by Sachs et al. Their analysis shows that the conformal channel mould reaches 
operational temperature faster than the conventional one, attaining a more uniform temperature distribution with efficient heat transfer capacity (Sachs et al., 2000).

While the use of conformal cooling channels on the one hand greatly enhances the injection molding process, on the other hand it is much more complicated fabricate them on respect of the straight ones.

The advancement of Solid Freeform Fabrication gives rise to the production of injection mould with intricate cooling channel geometry. Rapid tooling based on SFF technology includes SLM. Much research has focused on improving the geometric design of the cooling channel via SFF technologies. In 2001, Xu studied injection mould with complex cooling channels based on SFF processes. He described the conformal cooling layout that can be realized with substantial improvements in part quality and productivity (Xu et al., 2001).

At DIMeG of the Polytechnic of Bari, in collaboration with Elfim srl company of Gravina in Puglia (Ba), SLM was used to create a jig for welding of constituent parts of a titanium alloy intramedullary nail. The realization of this jig had two basic problems:

- $\quad$ cooling of the jig;

- conveyance of shielding gas on the welding area.

The cooling circuit of each component of the jig was designed with conformal channels in order to follow the welding areas and the nail seat, as the conformal cooling channels follow the geometry of the cavity in the dies for injection moulding. However, in this case, the situation was more complicated because of the need to provide even the conveyance of shielding gas.

The use of the shielding gas was necessary due to the high chemical reactivity of titanium, at high temperature, in presence of the oxygen. So, for a good quality joints and to prevent the oxides formation, the shielding of an inert gas was indispensable both during welding and during the cooling of the seam. Therefore, with the same concept usually adopted for the conformal cooling, was created a system of cylindrical channels, whit a diameter down to 1 $\mathrm{mm}$, in order to direct the shielding gas on weld areas.

Fig.12a and 13a show respectively the 3D CAD geometry of the upper and the lower component of the jig; Fig 12b and Fig 13b show the cooling (blue) and shielding gas (yellow) channels that were designed for the jig. Fig. 14 and Fig. 15 show respectively the fabricated upper and lower part of the jig, while Fig. 16 shows the coupling of the jig components.
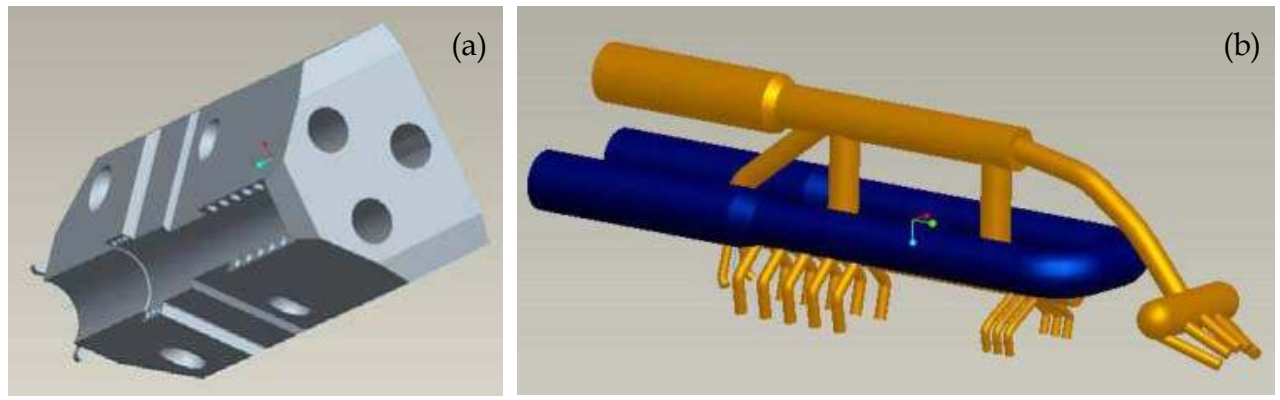

Fig. 12. 3D-CAD model of (a) the upper component of the jig; (b) cooling (blue) and shielding gas (yellow) channels in it 

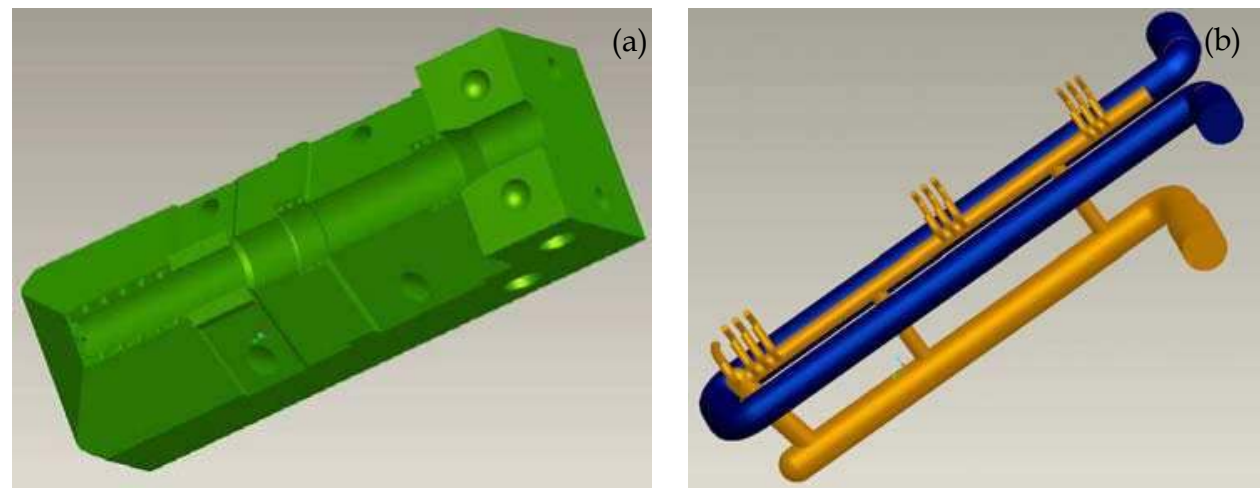

Fig. 13. 3D-CAD model of (a) the lower component of the jig; (b) cooling (blue) and shielding gas (yellow) channels in it

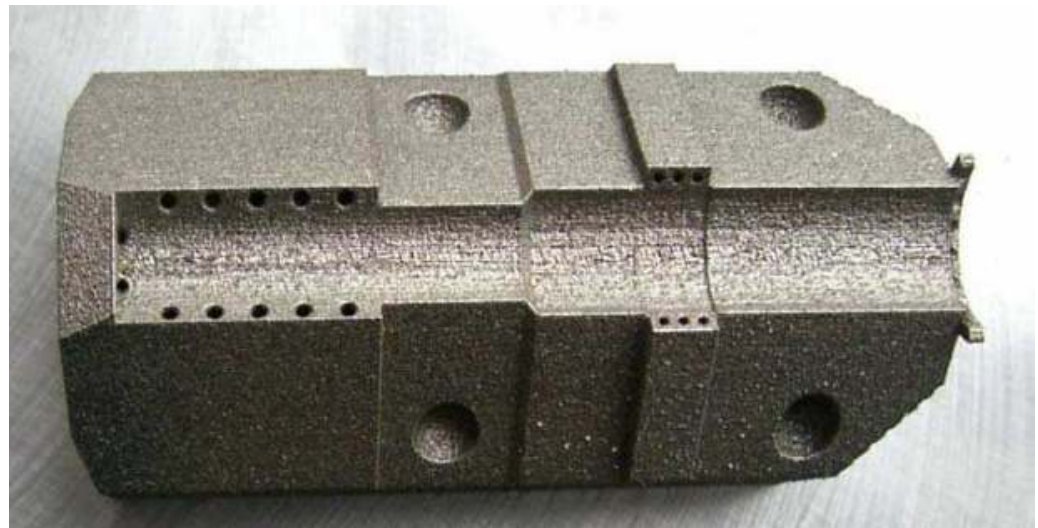

Fig. 14. Laser sintered upper component of the jig

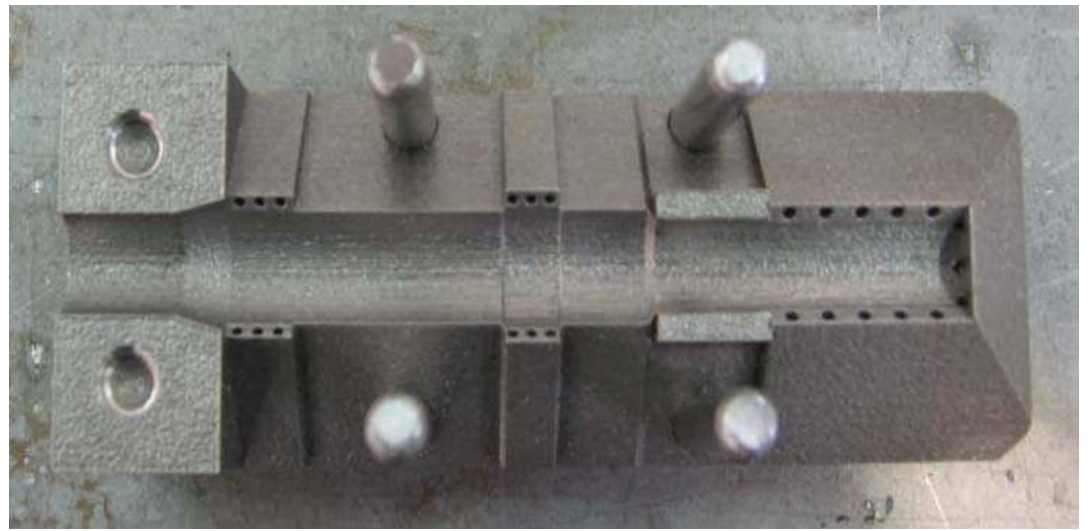

Fig. 15. Laser sintered lower component of the jig 


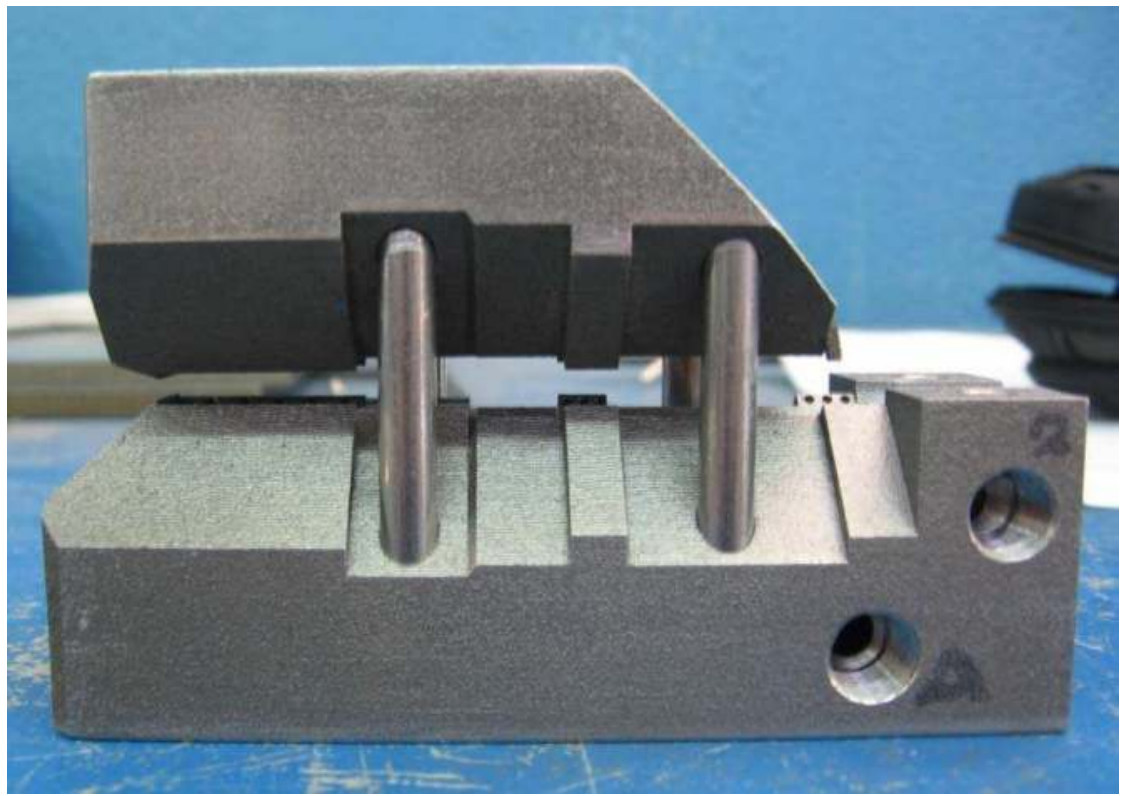

Fig. 16. Coupling of the jig components

\section{Conclusions}

The aim of this chapter was to describe capabilities and performances of the SLM process. First, experimental tests were performed in order to investigate characteristics of SLM parts. It was found that SLM parts could be produced with almost full density and with mechanical properties similar to those assured by traditional technologies. Later on it, a benchmark was built to study the accuracy of the process. It was found that the process has a good accuracy for nominal dimensions over $0.4 \mathrm{~mm}$; the dimensional error increases for values lower than $0.4 \mathrm{~mm}$ because the nominal size is gradually approaching to the laser spot diameter.

Finally, the capacity of the process in producing customized jigs for welding and reticular structures was illustrated.

\section{References}

Abe F., Osakada K., Shiomi M., Uematsu K. \& Matsumoto M. (2001). The manufacturing of hard tools from metallic powders by selective laser sintering. Journal of Materials Processing Technology, Vol. 111, No. 1-3, April 2001, 210-213, ISSN 0924-0136

Au K.M. \& Yu K.M. (2007). A scaffolding architecture for conformal cooling design in rapid plastic injection moulding, International Journal of Advanced Manufacturing Technology, Vol. 34, No. 5-6, September 2007, 496-515, ISSN: 0268-3768

Badrossamay, M. \& Childs, T.H.C. (2007). Further studies in selective laser melting of stainless and tool steel powders. International Journal of Machine Tools $\mathcal{E}$ Manufacture, Vol. 47, No. 5, April 2007, 779-784, ISSN: 0890-6955 
Campanelli, S.L; Contuzzi, N. \& Ludovico, A.D (2009). Selective Laser Melting: Evaluation of the performances of 18 AISI Marage 300 steel parts. Proceedings of 9th A.I.Te.M. Conference, ISBN 8895057074, pp. 109-110, September 2009, Torino, Italy

Campanelli, S.L; Contuzzi, N. \& Ludovico, A.D (2010). Manufacturing of 18 Ni Marage 300 steel samples by selective laser melting. Advanced Materials Research, Vol. 83-86, February 2010, 850-857, ISBN 0-87849-297-6

Cherng, J. G.; Shao, X.; Chen Y. \& Sferro P. R. (1998). Feature-Based Part Modeling And Process Planning For Rapid Response Manufacturing. Computers and Industrial Engineering, Vol. 34, No. 2, April 1998, 515-530, ISSN 0360-8352

Contuzzi, N. (2010). Analisi numerica e sperimentale di strutture innovative create mediante Fusione Laser Selettiva. Ph.D. Thesis in Mechanical and Biomechanical Design

Dewidar, M. M.; Lim J. K. \& Dalgarno, K.W. (2008). A Comparison between Direct and Indirect Laser Sintering of Metals. Journal of Materials Sciences and Technology, Vol. 24, No.2, 227-232, ISSN 1005-0302

Dimla, D.E.; Camilotto, M. \& Miani, F. (2005), Design and optimisation of conformal cooling channels in injection moulding tools. Journal of Materials Processing Technology, Vol. 164-165, May 2005, 1294-1300, ISSN 0924-0136

Dotcheva, M.; Millward, H. \& Thomas, D. (2008), Investigation of Rapid Manufactured Cellular Structures for Injection Moulding Tools. Proceedings of 6th CIRP Int. Conf. on Intelligent Computation in Manufacturing Engineering- CIRP ICME'08, ISBN 97888-900948-7-3, pp.369-374, July 2008, Naples, Italy

Evans, A. G.; Hutchinson, J. W.; Fleck, N. A.; Ashby, M. F. \& Wadley, H. N. G. (2001). The topological design of multifunctional cellular metals. Progress in Materials Science, Vol. 46, No. 3-4, April 2001, 309-327, ISSN 0079-6425

Fischer, P.; Romano, V.; Weber, H.P.; Karapatis, N.P.; Boillat, E. \& Glardon, R. (2003). Sintering of commercially pure titanium powder with a Nd:YAG laser source, Acta Materialia, Vol. 51, No. 6, April 2003, 1651-1662, ISSN 1359-6454

Fischer, P.; Romano, V.; Weber, H.P.; Karapatis, N.P.; Boillat, E. \& Glardon, R. (2003). Sintering of commercially pure titanium powder with a Nd:YAG laser source, Acta Materialia, Vol. 51, No. 6, April 2003, 1651-1662, ISSN 1359-6454

Gere, J. M. \& Timoshenko, S. P. (1984). Mechanics of materials, Stanley Thornes Publishers, ISBN 074873998X, Boston, USA

Hauser, C.; Childs, T.H.C. ; Taylor, C.M. \& Badrossamay, M. (2003). Direct selective laser sintering of tool steel powders to high density. Part A. Effect of laser beam width and scan strategy, Proceedings of the Solid Freeform Fabrication Symposium, pp. 644655, ISBN 1845440803, Austin, TX, August 2003, Emerald, Bingley, UK

Kannatey-Asibu, E. Jr. (2009). Principles Of Laser Materials Processing, John Wiley \& Sons Inc., ISBN 978-0-470-17798-3, Hoboken, New Jersey,

Kolossov, S.; Boillat, E.; Glardon, R.; Fischer P. \& Locher M. (2004). 3D FE simulation for temperature evolution in the selective laser sintering process. International Journal of Machine Tools \& Manufacture, Vol. 44, No. 2-3, February 2004, 117-123, ISSN 08906955

Kruf, W.; Van de Vorst, B.; Maalderink, H. \& Kamperman, N. (2006). Design for Rapid Manufacturing Functional SLS Parts, Proceedings of 5th CIRP Int. Conf. on Intelligent Computation in Manufacturing Engineering- CIRP ICME'06, ISBN 978-88-95028-01-9, pp. 609-613, July 2006, Ischia, Italy 
Kruth, J.P.; Van der Schueren, B.; Bonse, J.E. \& Morren, B. (1996). Basic powder metallurgical aspects in selective metal powder sintering. CIRP Annals - Manufacturing Technology, Vol. 45, No. 1, 1996, 183-186, ISSN 0007-8506

Kruth, J.P.; Froyen, L.; Morren, B. \& Bonse, J.E. (1997). Selective laser sintering of WC-Co 'hard metal' parts. Proceedings of 8th Int. Conf. on Production Engineering (ICPE-8), Rapid Product Development, pp.149-56, ISBN 0-412-81160X, Hokkaido University, Sapporo, Japan, August 1997, Chapman and Hall, London

Kruth, J.P.; Froyen, L.; Van Vaerenbergh, L.; Mercelis, P.; Rombouts M. \& Lauwers, B. (2004). Selective laser melting of iron-based powder. Journal of Materials Processing Technology, Vol. 149, No. 1-3, June 2004, 616-622, ISSN 0924-0136

Laoui, T.; Froyen, L. \& Kruth, J.P.(1998). Selective laser sintering of hard metal powders. Proceedings of Rapid Prototyping and Manufacturing Conference, pp. 435-467, ISSN : 1018-7375, Dearborn, Michigan, USA, April 1998

Lu, L.; Fuh, J.Y.H. \& Wong, Y.S. (2001). Laser-Induced Materials and Processes for Rapid Prototyping, Kluwer Academic Publishers, ISBN 0792374002, Norwell, USA

Lu, T. J. (1998). Heat transfer efficiency of metal honeycombs. International Journal of Heat and Mass Transfer, Vol. 42, No 11, June 1998 , 2031-2040, ISSN 0017-9310

Nickel, A.H.;. Barnett, D.M \& Prinz, F.B. (2001). Thermal stresses and deposition patterns in layered manufacturing. Materials Science and Engineering A, Vol. 317, No. 1-2, October 2001, 59-64, ISSN 0921-5093

Niu, H.J. \& Chang I.T.H. (1998). Liquid phase sintering of M3/2 high speed steel by selective laser sintering. Scripta Materialia, Vol. 39, No.1, June 1998, 67-72, ISSN 1359-6462

Niu, H.J. \& Chang I.T.H. (1999). Selective laser sintering of gas and water atomized high speed steel powders. Scripta Materialia, Vol. 41, No. 1, June 1999, 25-30, ISSN 13596462

Niu, H.J. \& Chang I.T.H. (2000). Selective laser sintering of gas atomized M2 high speed steel powder. Journal of Materials Science, Vol.35, No. 1, January 2000, 31-38, ISSN 0022-2461

Niu, H.J. \& Chang, T.H. (1999). Instability of scan tracks of selective laser sintering of high speed steel powder. Scripta Materialia, Vol. 41, No. 11, November 1999, 1229-1234, ISSN: 1359-6462

Pohl, H.; Simchi, A.; Issa, M. \& Dias, H.C. (2001). Thermal stresses in direct metal laser sintering, Proceedings of the Solid Freeform Fabrication Symposium, pp. 366-372, ISBN 1845440803, Austin, TX, August 2001, Emerald, Bingley, UK

Queheillalt, D. T.; Murtyb, Y. \& Wadleya, H. N.G. (2008). Mechanical properties of an extruded pyramidal lattice truss sandwich structure, Scripta Materialia, Vol. 58, No. 1, January 2008, 76-79, ISSN 1359-6462

Rehme, O. (2010). Cellular Design for Laser Freeform Fabrication, Cuvillier Verlag, ISBN 3869552735, Hamburg, Germany

Ring, M.; Dimla, D.E. \& Wimpenny, W.I. (2002). An Investigation of the effectiveness of Conformal Cooling channels and Selective Laser Sintering material in injection moulding tools, RPD 2002 Advanced Solutions in Product Development, Miranda Grande, Portugal, October 2002

Sachs, E.; Wylonis, E.; Allens, S.; Cima, M. \& Guo, H. (2000). Production of Injection Moulding Tooling with Conformal Cooling Channels Using the Three Dimensional Printing Process, Polymer Engineering and Science, Vol. 40, No. 5, 2000, 1232-1247. 
Santos, E. C.; Shiomi, M.; Osaka, K. \& Laoui, T. (2006). Rapid manufacturing of metal components by laser forming, International Journal of Machine Tools and Manufacture, Vol. 46, No. 12-13, October 2006, pp. 1459-1468, ISSN 0890-6955

Slocombe, A. \& Li, L. (2001). Selective laser sintering of TiC-Al2O3 composite with selfpropagating high-temperature synthesis. Journal of Materials Processing Technology, Vol. 118, No. 1-3, December 2001, 173-178, ISSN 0924-0136

Song, Y. (1997). Experimental study of the basic process mechanism for direct selective laser sintering of low-melting metallic powder. CIRP Annals - Manufacturing Technology, Vol. 46, No. 1,1997, 127-130, ISSN 0007-8506

Van der Schueren, B. \& Kruth, J.P. (1995). Laser Based Selective Metal Powder Sintering : A Feasibility Study. Proceedings of the Laser Assisted Net Shape Engineering, pp. 517-523, October 1994, Erlangen, Germany

Waterman, N.A.; Dickens P. (1994). Rapid product development in the USA, Europe and Japan. World Class Design To Manufacture, Vol. 1, No. 3, 27-36, ISSN 1352-3074

$\mathrm{Xu}, \mathrm{X}$; Sachs, E. \& Allen, S. (2001). The design of conformal cooling channels in injection molding tooling. Polymer Engineering And Science, Vol. 41, No. 7, July 2001, $1265-$ 1279, ISSN 0032-3888

Yadroitsev, I.; Shishkovsky , I.; Bertrand P. \& Smurov I. (2009). Manufacturing of finestructured 3D porous filter elements by selective laser melting. Applied Surface Science, Vol. 255, No. 10, March 2009, 5523-5527, ISSN 0169-4332

Yadroitsev, I.; Thivillon, L.; Bertrand, P. \& Smurov, I. (2007). Strategy of manufacturing components with designed internal structure by selective laser melting of metallic powder. Applied Surface Science, Vol. 254, No. 4, December 2007, 980-983, ISSN 01694332

Zhang, J. \& Ashby, M. F. (1992). The out-of-plane properties of honeycombs, International Journal of Mechanical Sciences, Vol. 34, No. 6, June 1992, pp. 475-489, ISSN 0020-7403 


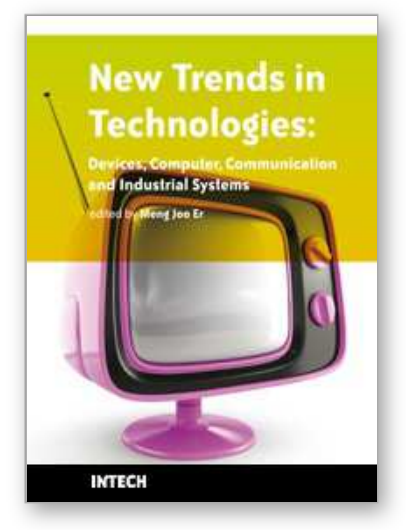

\section{New Trends in Technologies: Devices, Computer, Communication and Industrial Systems}

Edited by Meng Joo Er

ISBN 978-953-307-212-8

Hard cover, 444 pages

Publisher Sciyo

Published online 02, November, 2010

Published in print edition November, 2010

The grandest accomplishments of engineering took place in the twentieth century. The widespread development and distribution of electricity and clean water, automobiles and airplanes, radio and television, spacecraft and lasers, antibiotics and medical imaging, computers and the Internet are just some of the highlights from a century in which engineering revolutionized and improved virtually every aspect of human life. In this book, the authors provide a glimpse of new trends in technologies pertaining to devices, computers, communications and industrial systems.

\section{How to reference}

In order to correctly reference this scholarly work, feel free to copy and paste the following:

Sabina Luisa Campanelli, Nicola Contuzzi, Andrea Angelastro and Antonio Domenico Ludovico (2010). Capabilities and Performances of the Selective Laser Melting Process, New Trends in Technologies: Devices, Computer, Communication and Industrial Systems, Meng Joo Er (Ed.), ISBN: 978-953-307-212-8, InTech, Available from: http://www.intechopen.com/books/new-trends-in-technologies--devices--computer-communication-and-industrial-systems/capabilities-and-performances-of-the-selective-laser-melting-process

\section{INTECH}

open science | open minds

\section{InTech Europe}

University Campus STeP Ri

Slavka Krautzeka 83/A

51000 Rijeka, Croatia

Phone: +385 (51) 770447

Fax: +385 (51) 686166

www.intechopen.com

\section{InTech China}

Unit 405, Office Block, Hotel Equatorial Shanghai

No.65, Yan An Road (West), Shanghai, 200040, China

中国上海市延安西路65号上海国际贵都大饭店办公楼 405 单元

Phone: +86-21-62489820

Fax: $+86-21-62489821$ 
(C) 2010 The Author(s). Licensee IntechOpen. This chapter is distributed under the terms of the Creative Commons Attribution-NonCommercialShareAlike-3.0 License, which permits use, distribution and reproduction for non-commercial purposes, provided the original is properly cited and derivative works building on this content are distributed under the same license. 